\title{
Seasonal and Tidal Dynamics of Nutrients and Chlorophyll $a$ Concentration in Water at the Sundarbans Mangrove Ecosystems of Bangladesh
}

\author{
Md. Sakib Hasan Nion"1, Md. Sirajul Islam*1, Md. Enamul Hoq², Md. Humayun Kabir', \\ Mir Md. Mozammal Hoque ${ }^{1}$ \\ ${ }^{1}$ Department of Environmental Science and Resource Management, Mawlana Bhashani Science and \\ Technology University, Tangail-1902, Bangladesh \\ ${ }^{2}$ Bangladesh Fisheries Research Institute, Mymensingh-2201, Bangladesh \\ *Corresponding author (Email: islammstazu@yahaoo.com)
}

How to cite this paper: Nion, M.S.H., Islam, M.S., Hoq, M.E., Kabir, M.H. and Hoque, M.M.M. (2020). Seasonal and Tidal Dynamics of Nutrients and Chlorophyll $a$ Concentration in Water at the Sundarbans Mangrove Ecosystems of Bangladesh. Grassroots Journal of Natural Resources, 3(1): 50-67. Doi:

https://doi.org/10.33002/nr2581.6853.03015

Received: 21 January 2020

Reviewed: 05 March 2020

Provisionally Accepted: 13 March 2020

Revised: 19 March 2020

Finally Accepted: 22 March 2020

Published: 31 March 2020

Copyright (C) 2020 by author(s) and

The Grassroots Institute.

This work is licensed under the Creative Commons Attribution International License (CC BY 4.0).

http://creativecommons.org/licenses/by/4.0/
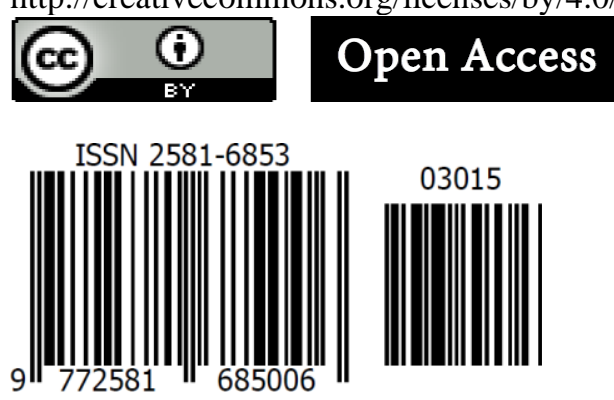

\begin{abstract}
The seasonal and tidal variations of physicochemical parameters, nutrient concentrations and chlorophyll $a$ concentration from the water of Passur river and Koromjol canal in the Sundarbans mangrove ecosystems were investigated during March 2018 to February 2019. Samples were collected from five sampling stations during March, August and November where these months were considered as pre-monsoon, monsoon and post-monsoon seasons, respectively. The nutrients $\mathrm{NH}_{3}$ $\mathrm{N}, \mathrm{NO}_{3}-\mathrm{N}, \mathrm{PO}_{4}-\mathrm{P}, \mathrm{SO}_{4}$ and Chlorophyll $a$ concentrations were found 0.001 to $0.09,3.5$ to $50,0.06$ to $5.4,30$ to 272 and 0.18 to $1.75 \mathrm{mg} / \mathrm{L}$, respectively, during high tides, and 0.001 to $0.39,4.2$ to $47,0.1$ to $2.75,20$ to 179 and 0.218 to $1.88 \mathrm{mg} / \mathrm{L}$, respectively, during low tides. The $\mathrm{NO}_{3}-\mathrm{N}$ was very high than suitable limit during both tides at monsoon and post-monsoon season. The $\mathrm{PO}_{4}-\mathrm{P}$ was found moderately high during both tides at all stations. The $\mathrm{SO}_{4}$ was found to be 187.8 and $76.87 \mathrm{mg} / \mathrm{L}$ during high tide, and 135.4 and $95.73 \mathrm{mg} / \mathrm{L}$ during low tides in pre-monsoon and post-monsoon, respectively, that were very high than water quality standards. The Passur river and the Koromjol canal were fluctuating seasonally and tidally in some magnitude and their variations can alter the water quality as well as the density and distribution of living organisms.
\end{abstract}

Keywords

Bangladesh, Chlorophyll a, Nutrients concentration, Sundarbans mangrove ecosystems, Tidal dynamics 
Doi: https://doi.org/10.33002/nr2581.6853.03015

\section{Introduction}

Sundarbans, the world's largest mangroves ecosystem covering $6000 \mathrm{~km}^{2}$ in Bangladesh, provides extensive variety of ecosystem as well as economic services with ecological importance of rich biodiversity including 355 species of birds, 49 species of mammals, 87 species of reptiles, 14 species of amphibians, 234 species of floras and 300 species of fishes (Rahaman et al., 2013). The Sundarbans also unswervingly supports the livelihood of about 7 million people breathing in the surroundings of the forest (Rahaman et al., 2013; Hossain et al., 2016). Aquatic environment of the Sundarbans is extremely complex in nature due to its dynamic coastal processes where the abiotic and biotic resources are highly variable in response to the processes (Rahaman et al., 2013). Mangrove ecosystems are important contributors of organic carbon and other nutrients to the adjacent coastal ecosystems and provide nutrients for phytoplankton growth, thus enhancing secondary production and promotion of commercial fisheries.

The distribution and behavior of nutrients are usually affected by tidal, seasonal and weather conditions (Senthilkumar et al., 2008). By this process, suspended matter, nutrients, heavy metals and other compounds from inland waters are deposited in mangrove environment (Hoq et al., 2006). Besides, anthropological activities as resource extraction, fishing, shrimp farming, agriculture and tourism also affect mangrove ecosystem. Consequently, the valuable ecosystem of Sundarbans has been subjected to considerable degradation (Rahman et al., 2013; Rahman et al., 2015). Nutrients exchange between land and sea in mangrove forest relatively depend on the availability and sources of water. Freshwater of the rivers originating from the Ganges meet in the intertidal rivers of Sundarbans, a region of transition between the freshwater and the saline water of the Bay of Bengal. Numerous rivers as Rupsha, Passur, Shibsa, Bhola, Baleshwar, Arpangashia, Kholpetua, Malancha, etc. sweeping into the Bay of Bengal through the Sundarbans and carry enormous amounts of nutrients that differ with streams and periods, affecting the productivity (Rahman et al., 2013). On the other hand, worldwide, mangrove nutrients loads have progressively increased in contemporary decades as a result of increasing population and industries. Accordingly, these increased nutrients may trigger the primary production and act as source of carbon, phosphorous, nitrite and sulphate in waters. Quality of water as habitat is most important for biodiversity of aquatic system and the quality of water varies with season and climate. So, assessing the water productivity with tide and time is very essential (Akhter et al., 2018; Kathiresan and Bingham, 2001).

For maintaining the productive as well as balanced aquatic environment, nutrients are the prime crucial elements (Islam et al., 2014). Phosphorus and nitrogen are the primary nutrients that in excessive amounts pollute the aquatic environment. Phosphorus occurs in dissolved organic and inorganic forms or attaches to sediment particles. When it remains in the sediments it is generally not available for use by algae; however, various chemical and biological processes can allow sediment phosphorus to be released back into the water (Rahaman et al., 2013; Rahman et al., 2014; MCPA, 2008; Islam et al., 2017). Sulphate can be found in the environment as a result of atmospheric and terrestrial processes. Major natural contributors of sulphate to the environment are sulphur released from erosion of evaporate deposits and sulphide containing rocks and minerals. One third of the sulphur reaching the environment is anthropogenic in the form of sulphate, sulphuric acid, hydrogen sulphide and SOx (Moreno-Casas et al., 2009). Chlorophyll $a$ is the pigment that allows plants and algae to photosynthesize, in which plants use the sun's energy to convert carbon-dioxide and water into oxygen and cellular material. It also absorbs energy from 
wavelengths of violet-blue and orange-red light, while reflecting green-yellow light (Suzuki et al., 1997; Islam et al., 2019).

All aquatic organisms depend directly on nutrients for their survival, growth and reproduction. Some nutrient levels are related to the chlorophyll $a$ availability of the water body, which means the availability of phytoplankton in the water. Thus, nutrient availability is directly related to the productivity of the water body. A shortage of nutrients causes the water body to be unproductive, and an excess of nutrients causes eutrophication by algal bloom and makes the water toxic (Islam et al., 2017; Islam et al., 2019). Thus, the nutrient concentration must be within suitable limit for a good aquatic environment and for better production of aquatic organisms (Rahaman et al., 2013). Apart from the importance of nutrients dynamics in mangrove waters, very few attempts have been made to investigate the concerns. The present study was an attempt to enumerate the nutrients and chlorophyll $a$ concentration in water with seasons and tide in selected five locations in the Sundarbans mangrove forest of Bangladesh.

\section{Materials and Methods}

Study area: The study area is in the Bangladesh part of Sundarbans that lies between the geographical coordinates of $21^{\circ} 45^{\prime}$ to $22^{\circ} 30^{\prime} \mathrm{N}$ and $89^{\circ} 00^{\prime}$ to $90^{\circ} 00^{\prime} \mathrm{E}$. Sundarbans is the prime example of the estuary of the Ganges and the Brahmaputra river systems in the Bay of Bengal. This biologically and ecologically rich and diverse eco-region is located in Khulna and Bagerhat districts under Khulna division of Bangladesh. The area experiences a subtropical monsoon climate with an annual rainfall of 1600 to $1800 \mathrm{~mm}$ and severe cyclonic storms (Haque, 2008). The study area was divided into five sampling stations namely S1: Passur river $\left(22^{\circ} 03.107^{\prime} \mathrm{N}\right.$ to $\left.089^{\circ} 58.329^{\prime} \mathrm{E}\right), \mathrm{S} 2$ : Passur river $\left(22^{\circ} 25.680^{\prime} \mathrm{N}\right.$ to $\left.089^{\circ} 35.680^{\prime} \mathrm{E}\right), \mathrm{S} 3$ : Koromjol canal $\left(22^{\circ} 25.733^{\prime} \mathrm{N}\right.$ to $\left.089^{\circ} 35.406^{\prime} \mathrm{E}\right), \mathrm{S} 4$ : Koromjol canal $\left(22^{\circ} 25.702^{\prime} \mathrm{N}\right.$ to $\left.089^{\circ} 35.130^{\prime} \mathrm{E}\right)$ and $\mathrm{S} 5:$ Koromjol canal $\left(22^{\circ} 25.726^{\prime} \mathrm{N}\right.$ to $\left.089^{\circ} 34.944^{\prime} \mathrm{E}\right)$.

Sample collection: The water samples were collected from 5 stations at Sundarbans mangrove forest during March, August and November in 2018 that can be named as pre-monsoon (March to May), monsoon (June to October) and post-monsoon (October to February) seasons, respectively. To analyze the water quality parameters, $500 \mathrm{ml}$ water was collected from each sampling points in plastic bottles with double stoppers. Before sampling, the bottles were cleaned and washed with detergent solution and treated with $5 \% \mathrm{HNO}_{3}$ overnight. The bottles were finally rinsed with deionized water and dried. After sampling, the bottles were screwed carefully and marked with the respective identification number and brought to laboratory.

Sample analysis: The samples collected from Passur river and Koromjol canal were analyzed and compared with the standard level of water quality parameters. The following analyses were done from the collected water samples: temperature, $\mathrm{pH}$, dissolved oxygen (DO), salinity, electrical conductivity (EC), total dissolved solids (TDS), ammonia $\left(\mathrm{NH}_{3}-\mathrm{N}\right)$, nitrate $\left(\mathrm{NO}_{3}-\mathrm{N}\right)$, phosphate $\left(\mathrm{PO}_{4}-\mathrm{P}\right)$, sulfate $\left(\mathrm{SO}_{4}\right)$ and chlorophyll $a$. The study was conducted through experimental method and experimental data were collected and processed carefully. The physico-chemical parameters were analyzed in the laboratory of the Department of Environmental Science and Resource Management of the Mawlana Bhashani Science and Technology University, Tangail. Temperature and $\mathrm{pH}$ were determined by the thermometer and digital $\mathrm{pH}$ meter, respectively. Buffer solution containing $\mathrm{pH} 7.0$ was used to calibrate the digital $\mathrm{pH}$ meter. Salinity was analyzed by Mohr's 
method (Eaton et al., 1995). The DO was determined by digital DO meter where sodium thiosulphate $(0.025 \mathrm{~N})$ was used as a reagent. EC and TDS were determined by EC and TDS meter, respectively. Samples were analyzed in the Water Quality Laboratory of Bangladesh Fisheries Research Institute (BFRI), Mymensingh, for measuring concentrations of $\mathrm{NH}_{3}-\mathrm{N}, \mathrm{NO}_{3}-\mathrm{N}_{1} \mathrm{PO}_{4}-\mathrm{P}$ and $\mathrm{SO}_{4}$. A high-definition spectrophotometer was used for estimating the concentration of major water nutrients. During analysis, $\mathrm{PO}_{4}-\mathrm{P}$ and $\mathrm{SO}_{4}$ were determined by the PhosVer 3 (USEPA, 2008) and SulfaVer 4 method (Ajwa and Tabatabai, 1993), respectively; while $\mathrm{NH}_{3}-\mathrm{N}$ was measured by Salicylate method (Le and Boyd, 2012); and $\mathrm{NO}_{3}-\mathrm{N}$ was measured by Cadmium Reduction method (EPA, 2007). Seasonal and tidal variations of nutrient concentrations were evaluated by calculating means and standard errors from the total number of samples taken for each analytic method during high and low tide within each sampling date. The chlorophyll $a$ of water samples was analyzed by 90\% acetone method in the Biochemistry and Molecular Biology Laboratory of the Mawlana Bhashani Science and Technology University.

Data analysis: The collected data were compiled and tabulated in proper form and were subjected to statistical analysis. The Microsoft Office Excel software was used to present and interpret the collected data accordingly.

\section{Results and Discussion}

\section{Physico-chemical water quality}

Temperature: The temperature ranged from 25.6 to $28.7,22.3$ to 24.3 and 24.1 to $25^{\circ} \mathrm{C}$ during high tide, and 25.4 to $28.2,23.8$ to 24.3 and 24 to $24.9^{\circ} \mathrm{C}$ during low tide over pre-monsoon, monsoon and post-monsoon seasons, respectively (Table 1). During high tide, the highest and lowest temperatures were 28.47 and $22.36^{\circ} \mathrm{C}$ at $\mathrm{S} 3$ in pre-monsoon and at $\mathrm{S} 1$ in monsoon season, respectively. Conversely, during low tide, the highest $\left(28.17^{\circ} \mathrm{C}\right)$ and lowest $\left(23.9^{\circ} \mathrm{C}\right)$ temperatures were found at $\mathrm{S} 1$ in pre-monsoon and at $\mathrm{S} 2$ in monsoon, respectively. The water temperature ranged from 23 to $27^{\circ} \mathrm{C}$ along the mangrove area of Kundapur (Kumar and Kumara, 2011) and ranged from 26 to $28^{\circ} \mathrm{C}$ at the Vedaranyam mangrove forest (Ramamurthy et al., 2012).

$\mathrm{pH}$ : The $\mathrm{pH}$ ranged from 7.80 to $8.55,7.60$ to 8.65 and 7.96 to 8.68 during high tide, and 8.20 to $8.70,8.10$ to 8.62 and 8.30 to 8.70 during low tide at pre-monsoon, monsoon and post-monsoon seasons, respectively (Table 1). During high tide, the highest $\mathrm{pH}$ was 8.55 at $\mathrm{S} 3$ in post-monsoon and lowest was 7.82 at S3 in monsoon season. During low tide, the highest (8.66) and lowest (8.2) $\mathrm{pH}$ were found at $\mathrm{S} 2$ in post-monsoon and at $\mathrm{S} 4$ in monsoon season, respectively. The $\mathrm{pH}$ was higher during low tide than high tide at maximum stations over the three seasons.

DO: The DO concentration ranged from 7.85 to $11.68,7.85$ to 12.54 and 8.48 to $13.13 \mathrm{mg} / \mathrm{L}$ during high tide, and 7.45 to $8.61,8.66$ to 12.48 and 8.65 to $14.39 \mathrm{mg} / \mathrm{L}$ during low tide in pre-monsoon, monsoon and post-monsoon seasons, respectively (Table 1). In high tide, the highest DO (11.87 $\mathrm{mg} / \mathrm{L})$ was found at $\mathrm{S} 1$ during post-monsoon than pre-monsoon $(11 \mathrm{mg} / \mathrm{L})$ at $\mathrm{S} 1$ and monsoon $(11.76 \mathrm{mg} / \mathrm{L})$ at $\mathrm{S} 5$. On the other hand, the lowest $(8.12 \mathrm{mg} / \mathrm{L})$ was found at $\mathrm{S} 3$ during monsoon followed by pre-monsoon $(8.52 \mathrm{mg} / \mathrm{L})$ at $\mathrm{S} 3$ and post-monsoon $(9.77 \mathrm{mg} / \mathrm{L})$ at $\mathrm{S} 4$. In low tide, the highest $(11.33 \mathrm{mg} / \mathrm{L})$ was found at S5 during post-monsoon than pre-monsoon $(10.87 \mathrm{mg} / \mathrm{L})$ at S3 and monsoon $(11.14 \mathrm{mg} / \mathrm{L})$ at $\mathrm{S} 3$. However, the lowest $(8.79 \mathrm{mg} / \mathrm{L})$ was found at $\mathrm{S} 4$ during premonsoon than monsoon $(9.26 \mathrm{mg} / \mathrm{L})$ at $\mathrm{S} 4$ and post-monsoon $(8.92 \mathrm{mg} / \mathrm{L})$ at $\mathrm{S} 3$. The higher level 
of DO in post-monsoon (4.37 to $7.03 \mathrm{mg} / \mathrm{L})$ and dry winter (4.37 to $6.23 \mathrm{mg} / \mathrm{L}$, whereas the monsoon period showed a lower DO (3.90 to $4.63 \mathrm{mg} / \mathrm{L})$ in the river water of the Sundarbans (Rahaman et al., 2013).

Salinity: The salinity ranged from 0.134 to $0.251,0.093$ to 0.187 and 0.165 to $0.361 \%$ during high tide, and 0.117 to $0.210,0.099$ to 0.192 and 0.158 to $0.317 \%$ during low tide in pre-monsoon, monsoon and post-monsoon seasons, respectively (Table 1). During high tide, the highest $(0.321 \%)$ and lowest $(0.110 \%)$ salinities were found at S4 in post-monsoon and at S2 in monsoon period, respectively. During low tide, the highest and lowest salinities were 0.280 and $0.122 \%$ in postmonsoon and monsoon season at same station (S4), respectively. The water salinity of the Sundarbans mangrove forest steadily increased to its maximum in pre-monsoon and started declining in monsoon season (Hoq et al., 2006), and ranged from 1.2 to $2.0 \%$ during high and low tide in the western part of Sundarbans (Sarkar et al., 2013).

EC: The EC ranged from 756 to 3257,712 to 2765 and 1706 to $1799 \mu \mathrm{s} / \mathrm{cm}$ with mean contents of $1599.79,1482.86$ and $1746.06 \mu \mathrm{s} / \mathrm{cm}$ during high tide in pre-monsoon, monsoon and postmonsoon, respectively (Table 1). In high tide, the highest EC was $2749.33 \mu \mathrm{s} / \mathrm{cm}$ at S5 and lowest was $745 \mu \mathrm{s} / \mathrm{cm}$ at $\mathrm{S} 1$ during monsoon season. In low tide, the highest and lowest EC were 3241.33 $\mu \mathrm{s} / \mathrm{cm}$ at $\mathrm{S} 3$ and $343.33 \mu \mathrm{s} / \mathrm{cm}$ at $\mathrm{S} 1$ during pre-monsoon and monsoon seasons, respectively. The EC contents were lower during the monsoon than the pre-monsoon period in the eastern part of the forest (Hoq et al., 2006). The EC contents were recorded moderately higher in the Sundarbans western part than the present contents of EC in Sundarbans water (Rahman et al., 2013).

TDS: The TDS ranged from 638 to 3456, 306 to 2213 and 1139 to 1402 ppm during high tide, and 351 to 3461,213 to 2244 and 1254 to 1448 ppm during low tide over pre-monsoon, monsoon and post-monsoon seasons, respectively (Table 1). During high tide, the highest (3239.66 ppm) was found at S5 in pre-monsoon than post-monsoon (1892.33 ppm) at S4 and monsoon (2135.66 ppm) at S5. On the other hand, the lowest (317 ppm) was found at S3 than 470.33 ppm at S1 and 498 ppm at $\mathrm{S} 2$ in monsoon season. During low tide, the highest TDS concentration was found 3158.33 ppm at S5 in pre-monsoon followed by $2191.66 \mathrm{ppm}$ at S3 and $2220.66 \mathrm{ppm}$ at S4 in monsoon season. However, the lowest was found $221.66 \mathrm{ppm}$ at $\mathrm{S} 2$ in monsoon than post-monsoon (258.66 ppm) at S1 and pre-monsoon (423.33 ppm) at S1. With the decay of plants and animals, dissolved organic particles are released and can contribute to the TDS concentration in Sundarbans water. The mean TDS concentrations ranged from 1716.67 to 1870,2100 to 2263.33 and 902.67 to 1319 ppm during pre-monsoon, monsoon and post-monsoon season, respectively (Rahman et al., 2013).

\section{Nutrients in water}

Ammonia $\left(\mathrm{NH}_{3}-\mathrm{N}\right)$ : The mean $\mathrm{NH}_{3}-\mathrm{N}$ concentrations were $0.035,0.037$ and $0.07 \mathrm{mg} / \mathrm{L}$ during high tide in pre-monsoon, monsoon and post-monsoon, respectively (Figure 1). During high tide, the highest $(0.06 \mathrm{mg} / \mathrm{L})$ was found at $\mathrm{S} 2$ and $\mathrm{S} 5$ in post-monsoon whereas lowest $(0.002 \mathrm{mg} / \mathrm{L})$ was found at $\mathrm{S} 2$ in pre-monsoon season. The mean $\mathrm{NH}_{3}-\mathrm{N}$ concentrations were $0.078,0.034$ and 0.052 $\mathrm{mg} / \mathrm{L}$ during low tide in pre-monsoon, monsoon and post-monsoon season, respectively (Figure 2). During low tide, the highest $(0.17 \mathrm{mg} / \mathrm{L})$ and lowest $(0.02 \mathrm{mg} / \mathrm{L})$ both were found in pre-monsoon season at $\mathrm{S} 3$ and $\mathrm{S} 5$, respectively. Changes of $\mathrm{NH}_{3}-\mathrm{N}$ concentrations during high and low tides were very diminutive. The $\mathrm{NH}_{3}-\mathrm{N}$ concentrations ranged from 0.001 to $0.33 \mathrm{mg} / \mathrm{L}$ in Sundarbans 
Doi: https://doi.org/10.33002/nr2581.6853.03015

water (IWM, 2003), which are closely similar with recorded $\mathrm{NH}_{3}-\mathrm{N}$ concentrations during low tide at pre-monsoon season in the present study.

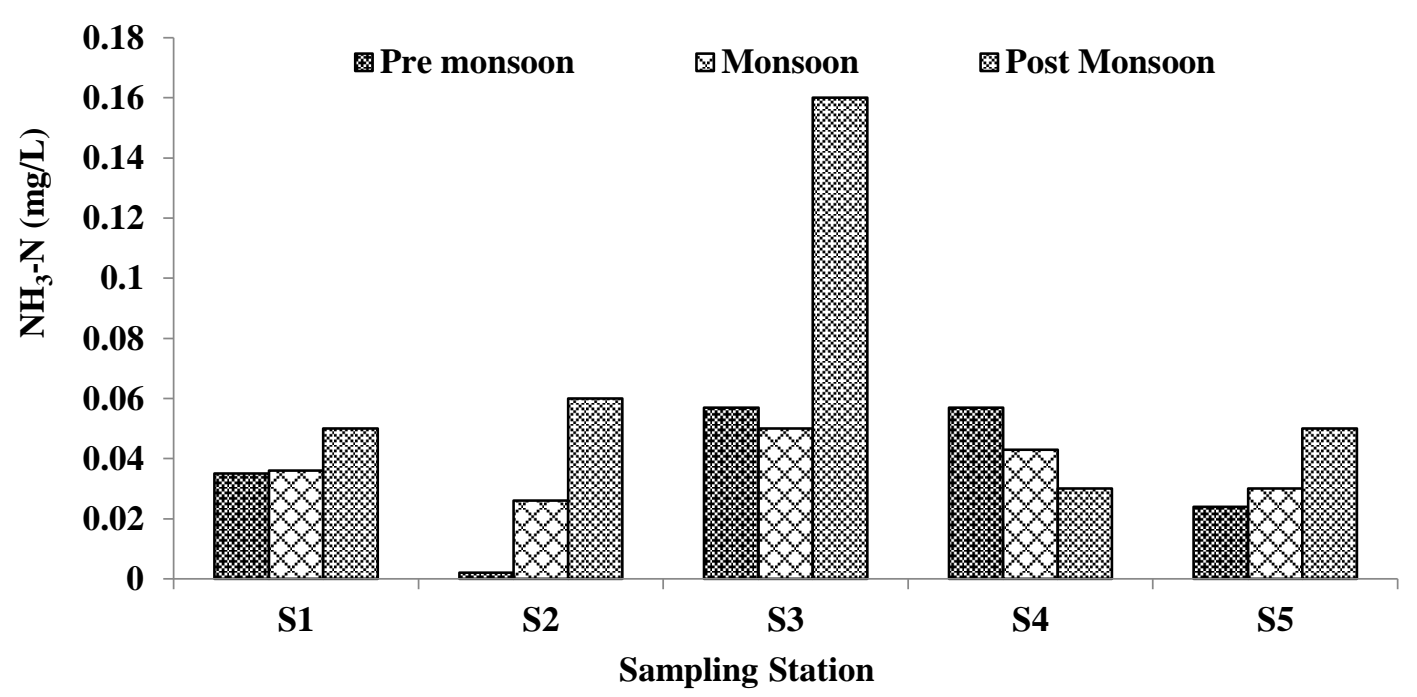

Figure 1: Seasonal variations of $\mathrm{NH}_{3}-\mathrm{N}$ concentrations in water during high tide at different stations

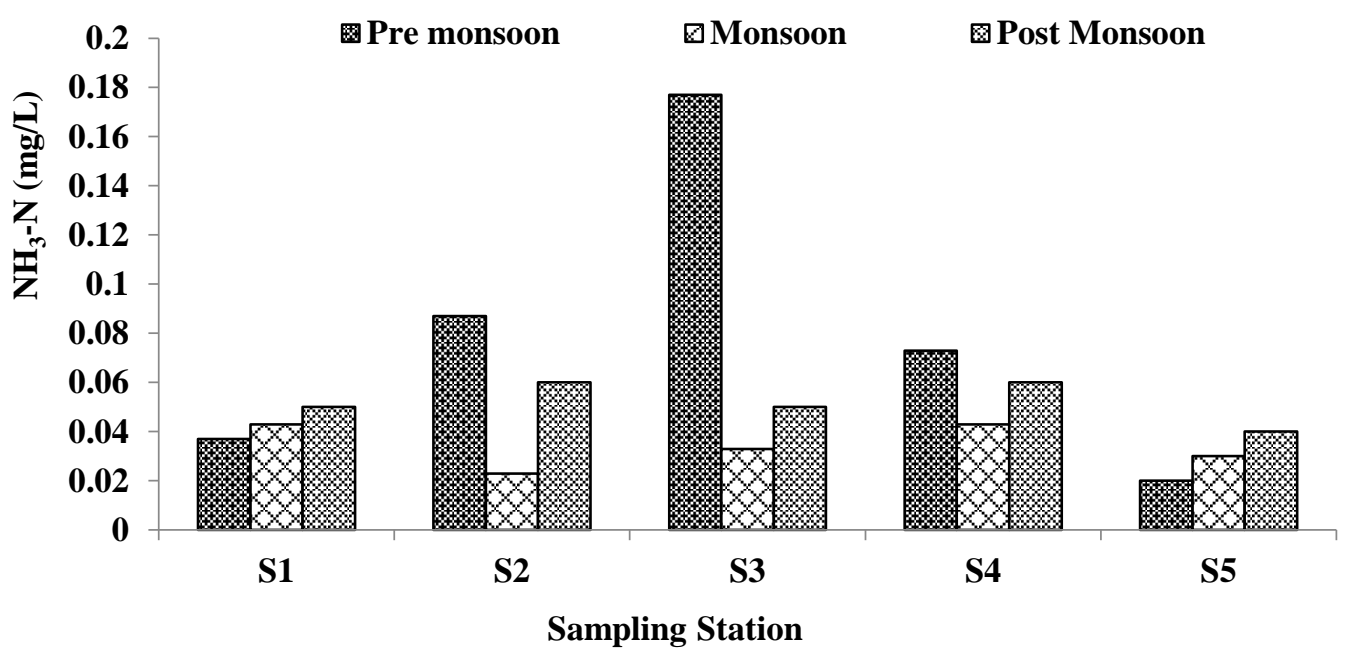

Figure 2: Seasonal variations of $\mathrm{NH}_{3}-\mathrm{N}$ concentrations in water during low tide

Nitrate $\left(\mathrm{NO}_{3}-\mathrm{N}\right)$ : The $\mathrm{NO}_{3}-\mathrm{N}$ concentrations ranged from 3.5 to $12.3,8.4$ to 27.2 and 5 to $50 \mathrm{mg} / \mathrm{L}$ during high tide, and 6.1 to $12.2,4.2$ to 28.2 and 10 to $47 \mathrm{mg} / \mathrm{L}$ during low tide in the study area at pre-monsoon, monsoon and post-monsoon seasons, respectively. During high tide, the highest $31.67 \mathrm{mg} / \mathrm{L}$ at $\mathrm{S} 3$ and the lowest $8.87 \mathrm{mg} / \mathrm{L}$ at $\mathrm{S} 1$ were found in post-monsoon and pre-monsoon season, respectively (Figure 3). During low tide, the highest $31.67 \mathrm{mg} / \mathrm{L}$ and the lowest $7.8 \mathrm{mg} / \mathrm{L}$ were found at S3 in post-monsoon and at S2 in pre-monsoon season, respectively (Figure 4). Mean concentrations of $\mathrm{NO}_{3}-\mathrm{N}$ were found $9.48,19.07$ and $22.6 \mathrm{mg} / \mathrm{L}$ during high tide, and 9.33, 17.2 
Doi: https://doi.org/10.33002/nr2581.6853.03015

and $23.2 \mathrm{mg} / \mathrm{L}$ during low tide over pre-monsoon, monsoon and post-monsoon seasons, respectively. The $\mathrm{NO}_{3}-\mathrm{N}$ concentration was found 0.04 to $0.46 \mathrm{mg} / \mathrm{L}$ with an average of $0.15 \mathrm{mg} / \mathrm{L}$ over the three sampling seasons (Rahman et al., 2013).

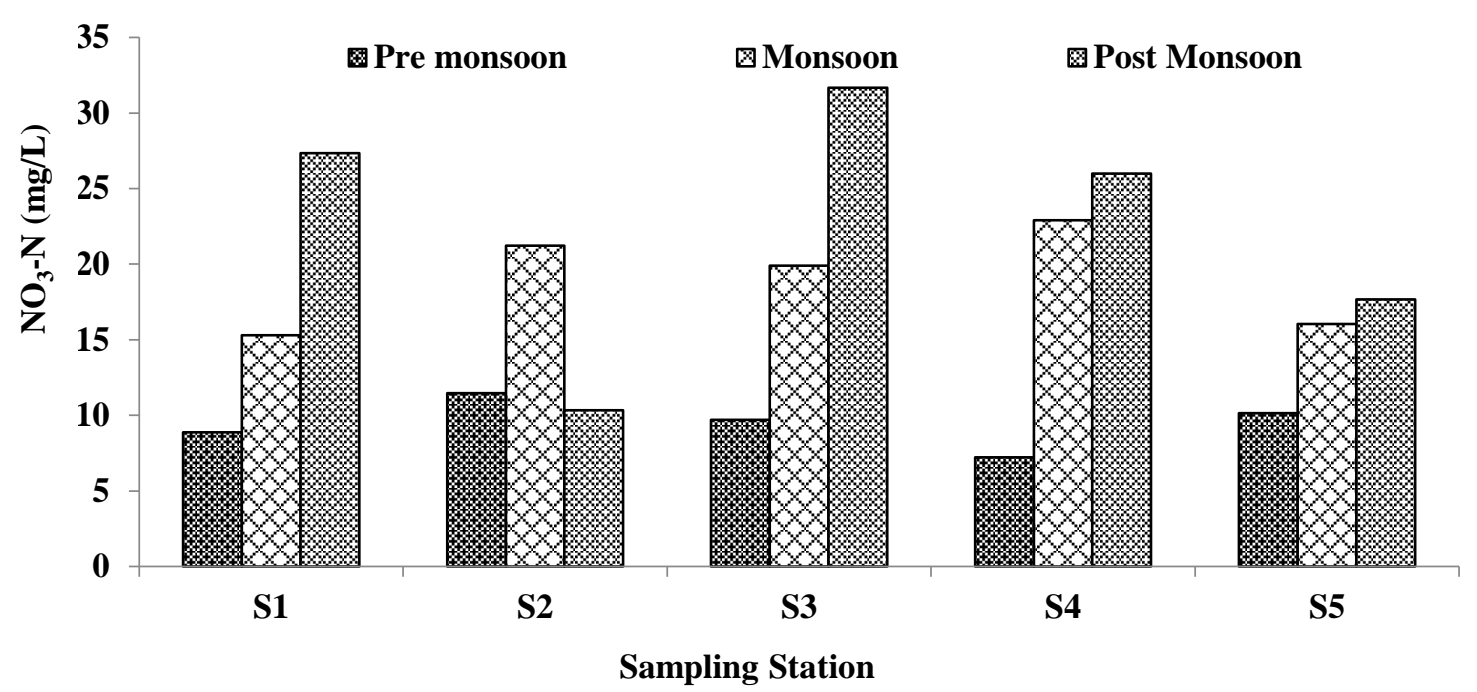

Figure 3: Seasonal variations of $\mathrm{NO}_{3}-\mathrm{N}$ concentrations in water during high tide at different stations

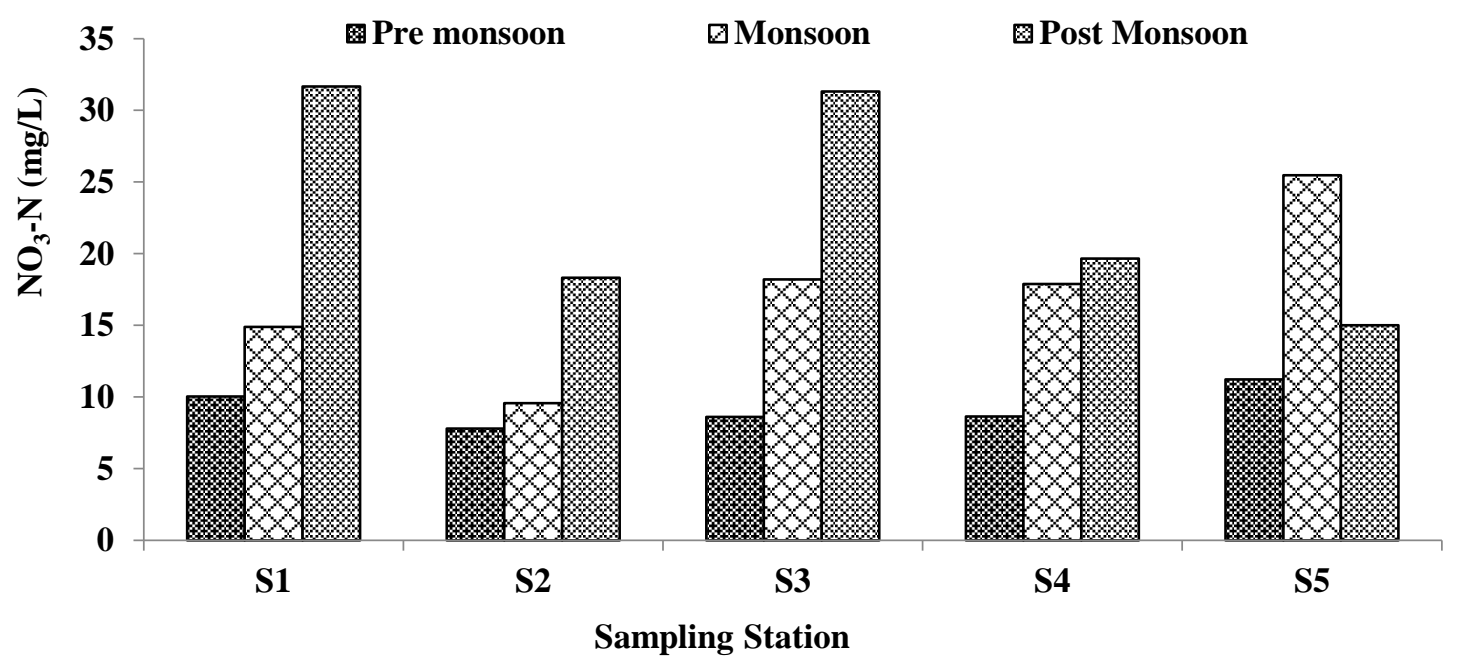

Figure 4: Seasonal variations $\mathrm{NO}_{3}-\mathrm{N}$ concentrations in water during low tide at different stations

Phosphate $\left(\mathrm{PO}_{4}-\mathrm{P}\right)$ : The $\mathrm{PO}_{4}-\mathrm{P}$ concentrations ranged from 0.27 to $5.4,0.06$ to 1.57 and 0.48 to $1.98 \mathrm{mg} / \mathrm{L}$ during high tide, and 0.41 to $2.75,0.1$ to 1.61 and 0.79 to $1.63 \mathrm{mg} / \mathrm{L}$ during low tide over pre-monsoon, monsoon and post-monsoon seasons, respectively. During high tide, the highest $\mathrm{PO}_{4}-\mathrm{P}$ concentrations $4.44 \mathrm{mg} / \mathrm{L}$ was found at $\mathrm{S} 1$ in pre-monsoon than $1.27 \mathrm{mg} / \mathrm{L}$ at $\mathrm{S} 4$ and 1.57 
$\mathrm{mg} / \mathrm{L}$ at $\mathrm{S} 5$ both in post-monsoon season, and lowest $\mathrm{PO}_{4}-\mathrm{P}$ concentration $0.28 \mathrm{mg} / \mathrm{L}$ was found at $\mathrm{S} 3$ in monsoon than $0.36 \mathrm{mg} / \mathrm{Lat} \mathrm{S} 5$ and $0.39 \mathrm{mg} / \mathrm{L}$ at $\mathrm{S} 2$ both in monsoon season (Figure 5).

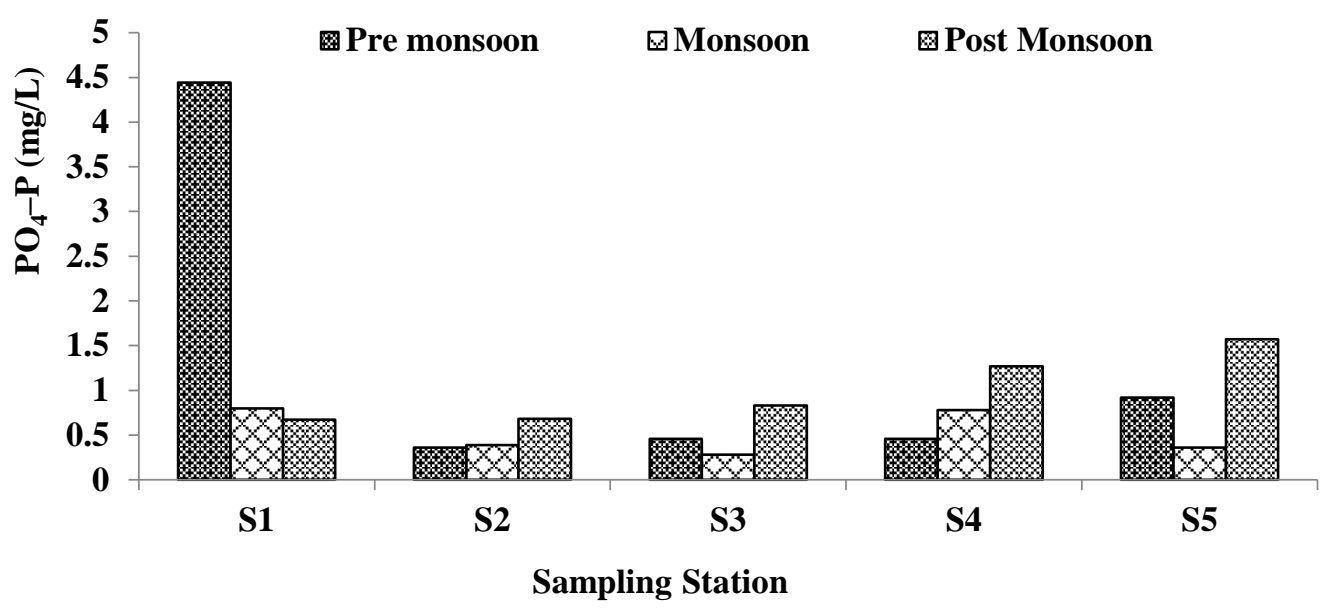

Figure 5: Seasonal variations of $\mathrm{PO}_{4}-\mathrm{P}$ concentrations in water during high tide

During low tide, the highest $\mathrm{PO}_{4}-\mathrm{P}$ concentrations $2.48 \mathrm{mg} / \mathrm{L}$ was found at $\mathrm{S} 1$ in pre-monsoon than $1.11 \mathrm{mg} / \mathrm{L}$ at $\mathrm{S} 3$ and $1.31 \mathrm{mg} / \mathrm{L}$ at $\mathrm{S} 4$ both in post-monsoon, and the lowest $\mathrm{PO}_{4}-\mathrm{P}$ concentrations $0.15 \mathrm{mg} / \mathrm{L}$ was found at $\mathrm{S} 4$ in monsoon than $0.26 \mathrm{mg} / \mathrm{L}$ at $\mathrm{S} 5$ and $0.48 \mathrm{mg} / \mathrm{L}$ at $\mathrm{S} 1$ both in monsoon season (Figure6). Mean $\mathrm{PO}_{4}-\mathrm{P}$ concentration during high tide $1.33,0.52$ and $1.004 \mathrm{mg} / \mathrm{L}$, and during low tide $0.95,0.43$ and $1.15 \mathrm{mg} / \mathrm{L}$ were found over pre-monsoon, monsoon and postmonsoon seasons, respectively. The mean phosphate concentrations as $\mathrm{PO}_{4}-\mathrm{P}$ measured at different tidal cycles over three sampling seasons were generally low, ranged from 0.05 to $0.42 \mathrm{mg} / \mathrm{L}$ with an average of $0.12 \mathrm{mg} / \mathrm{L}$ (Rahaman et al., 2013). A relatively low concentration of PO4-P was found 0.009 to $0.582 \mathrm{mg} / \mathrm{L}$ with an average of $0.115 \mathrm{mg} / \mathrm{L}$ in the mangrove area (IWM, 2003). The DoE defines the EQS of $\mathrm{PO}_{4}-\mathrm{P}$ as between 6 and $10 \mathrm{mg} / \mathrm{L}$ (DoE, 1991).

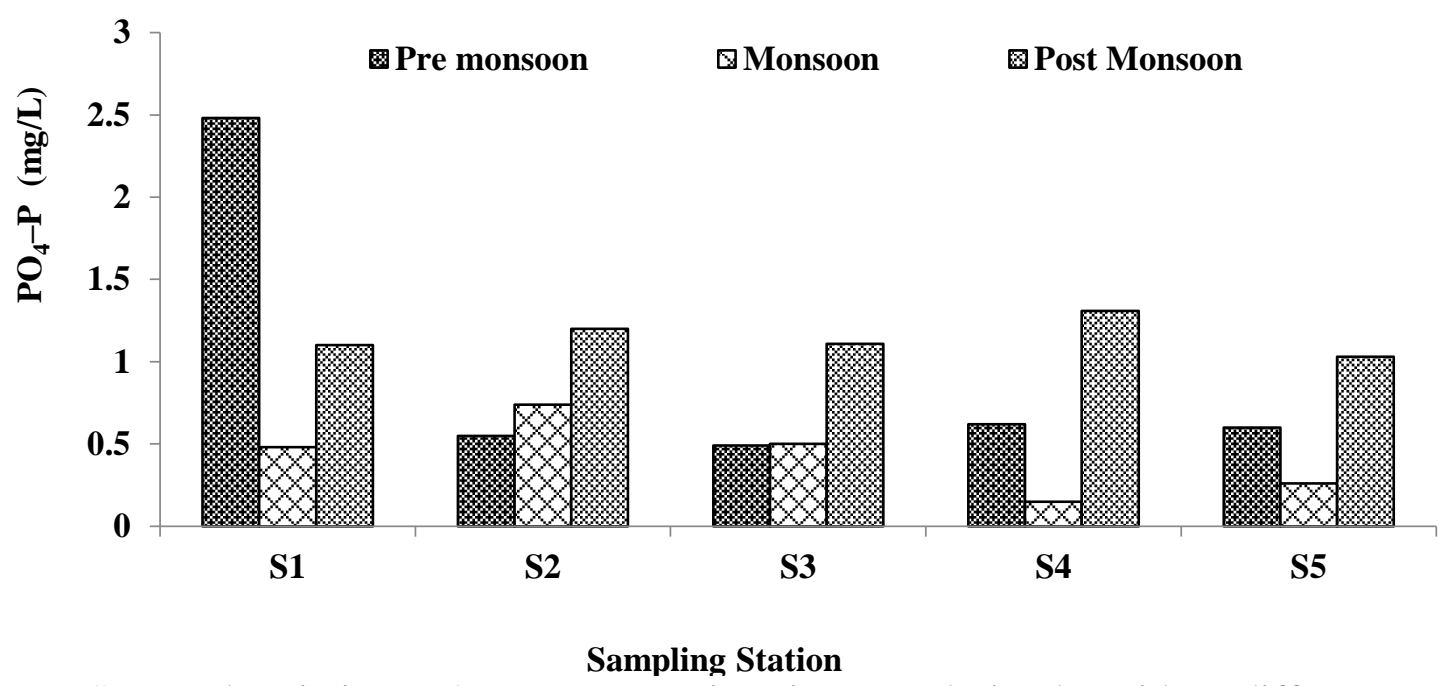

Figure 6: Seasonal variations $\mathrm{PO}_{4}-\mathrm{P}$ concentrations in water during low tide at different stations 
Sulfate $\left(\mathrm{SO}_{4}\right)$ : The $\mathrm{SO}_{4}$ concentrations ranged from 119 to 272,30 to 90,32 to $130 \mathrm{mg} / \mathrm{L}$ with mean concentrations $187.8,53.19$ and $76.87 \mathrm{mg} / \mathrm{L}$ found during high tide in pre-monsoon, monsoon and post-monsoon, respectively. During high tide the highest $264 \mathrm{mg} / \mathrm{L}$ at S2 and the lowest $40 \mathrm{mg} / \mathrm{L}$ at both S3 and S1 were found in pre-monsoon, and monsoon and post-monsoon season, respectively. In high tide, the $\mathrm{SO}_{4}$ values at maximum sampling stations were between suitable range during monsoon season which were found slightly increased during post-monsoon and highly increased during pre-monsoon (Figure 7). The $\mathrm{SO}_{4}$ concentrations ranged from 69 to 179, 20 to 80,60 to $130 \mathrm{mg} / \mathrm{L}$ with mean concentrations $135.4,45.8$ and $95.73 \mathrm{mg} / \mathrm{L}$ found during low tide over pre-monsoon, monsoon and post-monsoon, respectively. During low tide, the highest 176 $\mathrm{mg} / \mathrm{L}$ and the lowest $31 \mathrm{mg} / \mathrm{L}$ were found at $\mathrm{S} 3$ in pre monsoon and at S5 in monsoon period, respectively. In low tide, the $\mathrm{SO}_{4}$ values at maximum sampling stations were between suitable range during monsoon season which were found moderately higher during post monsoon and extremely higher during pre-monsoon (Figure 8).

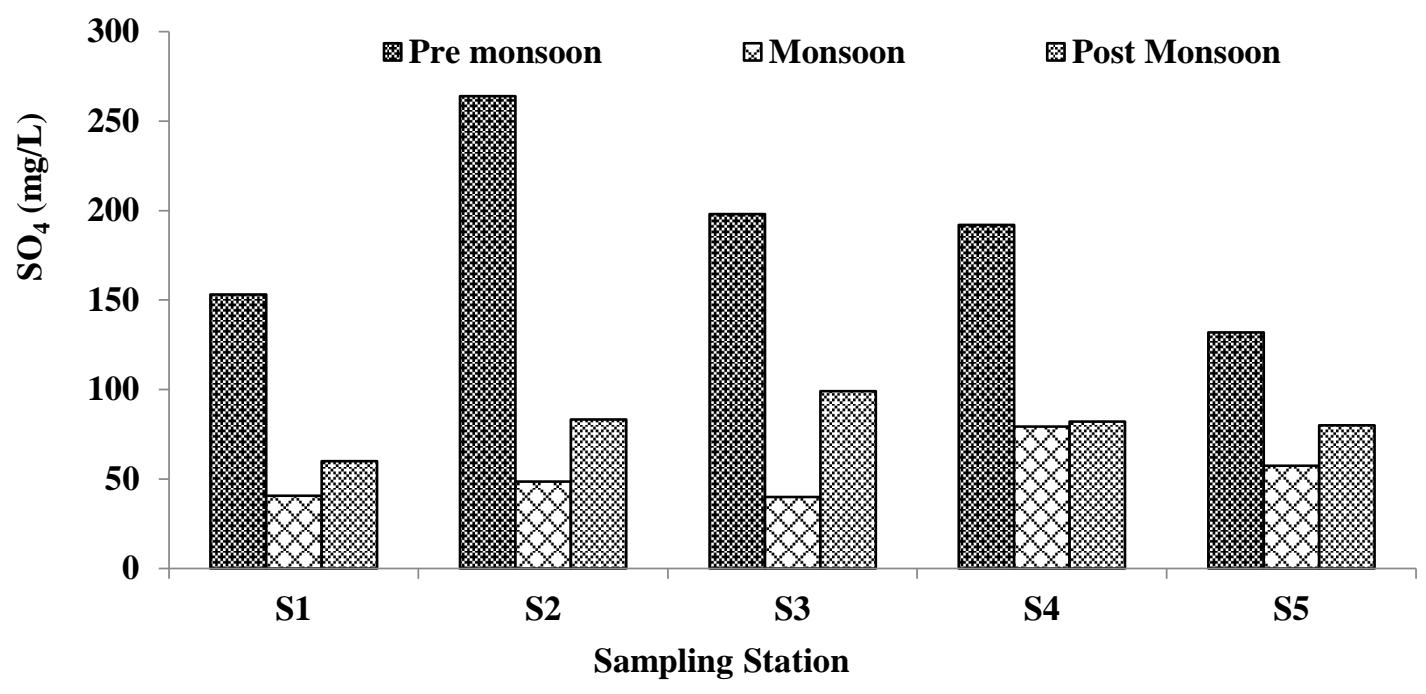

Figure 7: Seasonal variations of $\mathrm{SO}_{4}$ concentrations in water during high tide at different stations

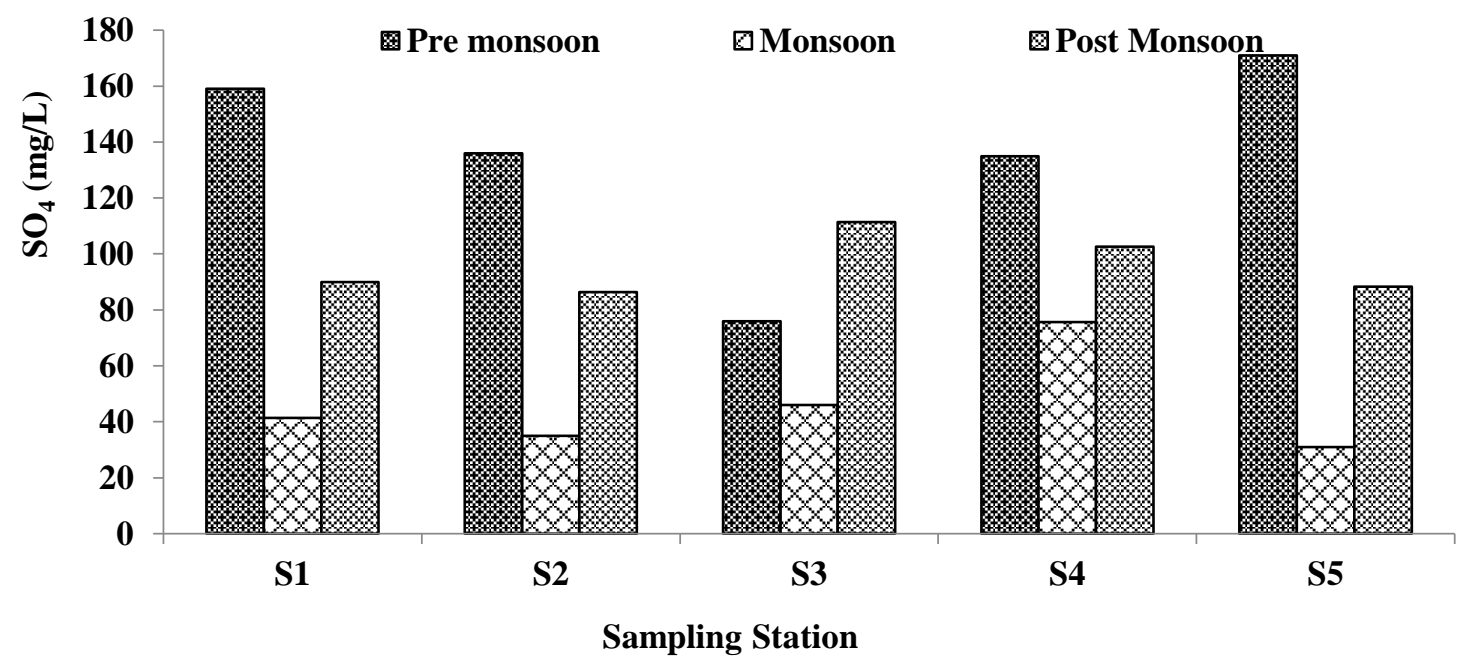

Figure 8: Seasonal variations of $\mathrm{SO}_{4}$ concentrations in water during low tide at different stations 
Doi: https://doi.org/10.33002/nr2581.6853.03015

\section{Chlorophyll $a$ in water}

The concentrations of chlorophyll $a$ ranged from 0.611 to $0.840,0.217$ to 1.168 and 0.180 to 1.75 $\mathrm{mg} / \mathrm{L}$ during high tide, and 0.638 to $0.883,0.218$ to 1.189 and 0.69 to $1.88 \mathrm{mg} / \mathrm{L}$ during low tide over pre-monsoon, monsoon and post-monsoon season, respectively. During high tide, the highest $1.29 \mathrm{mg} / \mathrm{L}$ and the lowest $0.345 \mathrm{mg} / \mathrm{L}$ were found at $\mathrm{S} 1$ in post-monsoon and at $\mathrm{S} 3$ in monsoon seasons, respectively (Figure 9). In high tide the chlorophyll $a$ concentrations $0.345 \mathrm{mg} / \mathrm{L}$ at S3 during monsoon and $0.52 \mathrm{mg} / \mathrm{L}$ at $\mathrm{S} 2$ during post-monsoon, were found similar to the standard range. During low tide, the highest $1.58 \mathrm{mg} / \mathrm{L}$ and the lowest $0.464 \mathrm{mg} / \mathrm{L}$ were found at $\mathrm{S} 4$ in postmonsoon and S2 in monsoon seasons, respectively (Figure 10). In low tide the concentrations of chlorophyll $a 0.464 \mathrm{mg} / \mathrm{L}$ at S2, $0.569 \mathrm{mg} / \mathrm{L}$ at S3 and $0.539 \mathrm{mg} / \mathrm{L}$ at $\mathrm{S} 4$ during monsoon season were similar to the standard value. Mean concentration of chlorophyll $a$ were found $0.788,0.973$ and $0.964 \mathrm{mg} / \mathrm{L}$ during high tide, and $0.789,0.649$ and $1.428 \mathrm{mg} / \mathrm{L}$ during low tide over the premonsoon, monsoon and post-monsoon seasons, respectively.

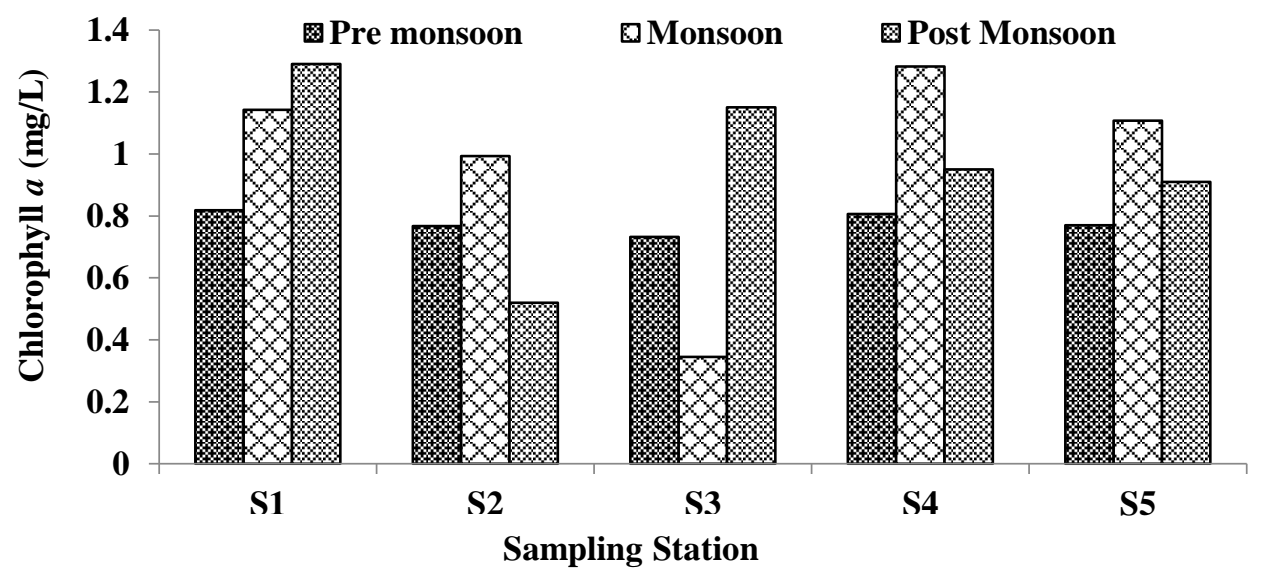

Figure 9: Seasonal variations of chlorophyll $a$ concentration in water during high tide

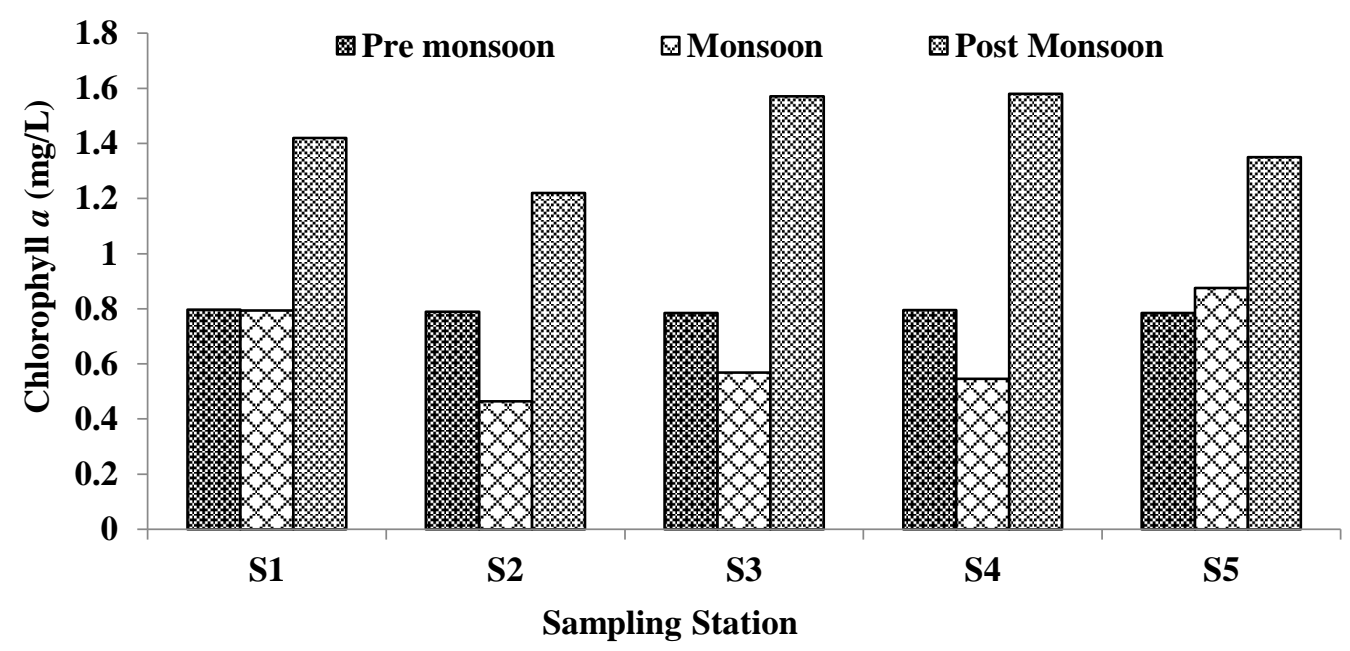

Figure 10: Seasonal variations of chlorophyll $a$ concentration in water during low tide 


\section{Seasonal and tidal dynamics of physicochemical properties in water}

Variation of temperature from pre-monsoon to monsoon season (25.66 to 22.37 at S1, 28.47 to 23.63 at S3, 28.43 to $24.13^{\circ} \mathrm{C}$ at S4) in both tides were observed during the study period, whereas a slight variation was found from high tide to low tide over maximum stations such as 22.37 to 23.90 at $\mathrm{S} 2,23.63$ to $24.13^{\circ} \mathrm{C}$ at $\mathrm{S} 3$ (Table 2). The $\mathrm{pH}$ ranged from 7.82 to 8.55 and 8.2 to 8.66 over all sampling seasons during high and low tide, respectively. The $\mathrm{pH}$ at maximum sampling statiopns during monsoon season (8.49 at S2, 8.06 at S3) slightly decreased during monsoon (8.16 at $\mathrm{S} 2,7.82$ at $\mathrm{S} 3$ ) which gradually increased (8.23 at S2, 8.55 at $\mathrm{S} 3$ ) during post monsoon season (Table 2). The DO ranged from 8.52 to $11.0,8.12$ to 11.46 and 8.93 to $11.87 \mathrm{mg} / \mathrm{L}$ during both tides over pre-monsoon, monsoon and post-monsoon season, respectively (Table 2).

Salinity ranged from 0.111 to $0.321 \%$ and 0.130 to $0.281 \%$ at all sampling stations over three seasons during high tide and low tide, respectively (Table 3). During pre-monsoon and monsoon season EC values showed a greater change from S1 to S3 between high and low tide (Table 3). In $\mathrm{S} 1$ and S2 during monsoon, in S3 and S4 during pre-monsoon and post-monsoonseason, showed a great difference of TDS concentrations between high and low tide (Table 3 ).

\section{Seasonal and tidal dynamics of nutrients and Chlorophyll $a$ in water}

The $\mathrm{NH}_{3}-\mathrm{N}$ concentrations ranged from 0.002 to 0.06 and 0.02 to $0.177 \mathrm{mg} / \mathrm{L}$ at all sampling stations over three seasons during high and low tide, respectively (Table 4). From $\mathrm{S} 1$ to $\mathrm{S} 5, \mathrm{NO}_{3}-\mathrm{N}$ concentrations showed a highly difference between high and low tide both pre-monsoon and postmonsoon. In post-monsoon, $\mathrm{NO}_{3}-\mathrm{N}$ concentrations showed slight change between two tides at all stations (Table 4). In all stations, $\mathrm{PO}_{4}-\mathrm{P}$ was found very higher than the suitable range (0.005 to 0.2 $\mathrm{mg} / \mathrm{L}$ ) during both tides at pre-monsoon and monsoon season. In monsoon season, $\mathrm{PO}_{4}-\mathrm{P}$ was found higher during both tides but they remained lower than the two remaining seasons (Table 4).

The $\mathrm{SO}_{4}$ ranged from 76 to 264,31 to 79.33 and 40 to $111.33 \mathrm{mg} / \mathrm{L}$ during both tides over premonsoon, monsoon and post-monsoon season, respectively (Table 5). Chlorophyll $a$ concentrations ranged from 0.345 to 1.29 , and 0.464 to $1.58 \mathrm{mg} / \mathrm{L}$ at all stations over three seasons during high and low tide, respectively. During high tide in pre-monsoon season, chlorophyll $a$ concentration $0.818 \mathrm{mg} / \mathrm{L}$ at $\mathrm{S} 1$ and $0.806 \mathrm{mg} / \mathrm{L}$ at $\mathrm{S} 4$ was higher than the value found in low tide. In monsoon season, chlorophyll $a$ concentations were found higher during high tide than low tide at all samplimng stations. During low tide, chlorophyll $a$ concentrations were found higher than the high tide at all stations (Table 5). The chlorophyll $a$ concentrations of the present study was almost similer of the standard when compared with previous studies (Table 6).

\section{Conclusion}

Nutrients balance of the Sundarbans mangrove ecosystem was influenced by the tidal cycle and seasonal variations as revealed by the changes in nutrients and chlorophyll $a$ in water at different seasons. The effect of tidal amplitude was important in determining in the extent of variations in nutrient and chlorophyll $a$ concentrations. Water quality of Passur river and Koromjol canal during different tides and seasons has impact on the nutrients and chlorophyll $a$ concentrations. The upstream and downstream flowing of water, fluctuations of tides and different seasons have greater impact on water quality of mangrove ecosystem. As a result, major nutrients and chlorophyll $a$ 
concentration in river water could have some effects on aquatic ecosystem in the Sundarbans mangrove.

\section{Acknowledgements}

Sincere appreciation to the University Grants Commission (UGC) of Bangladesh for financial support through the Research Cell of the Mawlana Bhashani Science and Technology University to carry out the research smoothly and successfully.

\section{References}

Ajwa, H.A. and Tabatabai, M.A. (1993). Comparison of some methods for determination of sulfate in soils. Communications in Soil Science and Plant Analysis, 24(15-16): 1817-1832. DOI: 10.1080/00103629309368920.

Akhter, M., Reza, M.S., Jamil, A.H.M.N. and Uddin, M.N. (2018). Assessment of water quality and seasonal variations based on aquatic biodiversity of Sundarbans mangrove forest, Bangladesh. IOSR Journal of Biotechnology and Biochemistry, 4(1): 6-15. DOI: 10.21767/2277-2871.1000109.

DoE (Department of Environment) (1991). Ministry of Environment and Forest. Peoples Republic of Bangladesh.

Eaton, A.D., Clesceri, L.S., Greenberg, A.E. and Franson, M.A.H. (1995). Standard methods for the examination of water and wastewater, American Public Health Association, Washington DC, pp. 254-256.

EPA (Environmental Protection Agency) (2007). Water quality standards handbook. EPA office of water science and technology, Washington DC.

Haque, M.I. (2008). Water Resource Management in Bangladesh. Anushilan, Chuadanga and Dhaka, 24-84 pp.

Hoq, M.E., Wahab, M.A. and Islam, M.N. (2006). Hydrographic status of Sundarbans mangrove, Bangladesh with special reference to post-larvae and juveniles fish and shrimp abundance. Wetlands Ecological Management, 14:79-93. DOI: 10.1007/s11273-005-2569-9.

Hossain, M.I., Nabi, M.R., Ansari, M.N.A., Latif, A., Mahmud, M.R. and Islam, M.S. (2016). Ecosystem services of the world largest mangrove forest Sundarbans in Bangladesh. International Journal of Innovation and Scientific Research, 27(1): 9-15.

Islam, M.S., Imran, M.H., Rimu, S.H., Kabir, M.H. and Suravi (2019). Water quality monitoring of aquaculture hatchery in Mymensingh region of Bangladesh. Journal of Environmental Science, 36: 15-22.

Islam, M.S., Kabir, M.H., Sifat, S.A., Meghla, N.T. and Tusher, T.R. (2014). Status of water quality from the Padma river at Bheramara point of Kushtia in Bangladesh. Bangladesh Journal of Environmental Science, 27: 110-115.

Islam, M.S., Shil, S.C., Kabir, M.H. and Hoq, M.E. (2017). Investigation of heavy metal contamination in fishes from Passur river near the Sundarbans mangroves of Bangladesh.

Journal of Environmental Science and Natural Resources, 10(1): 21-24. DOI: 10.3329/jesnr.v10i1.34689.

IWM (Institute of Water Modeling) (2003). Water quality of mangrove forest, Bangladesh.

Kathiresan, K. and Bingham, B.L. (2001). Biology of mangroves and mangrove ecosystems. Advances in Marine Biology, 40: 81-251. 
Kumar, K. and Kumara, V. (2011). Avifaunal diversity of mangrove ecosystem, Kundapura, Udupi district, Karnataka, India. Recent Research in Science and Technology, 3(10): 23-28.

Le, P.T.T. and Boyd, C.E. (2012). Comparison of Phenate and Salicylate methods for determination of Total Ammonia Nitrogen in freshwater and saline water. Journal of the World Aquaculture Society, 43(6): 885-889. DOI: 10.1111/j.1749-7345.2012.00616.x

MCPA (Minnesota Pollution Control Agency) (2008). Nutrients: phosphorus, nitrogen sources, impact on water quality- a general overview. Water quality/ impaired waters \# 3.22.

Moreno-Casas, P.A., Aral, H. and Sadus, A.V. (2009). Environmental impact and toxicology of sulphate. In: conference on environment, 2009, Santiago, Chile.

Rahaman, S.M.B., Sarder, L., Rahaman, M.S., Ghosh, A.K., Biswas, S.K., Siraj, S.M.S., Huq, K.A., Hasanuzzaman, A.F.M. and Islam, S.S. (2013). Nutrient dynamics in the Sundarbans mangrove estuarine system of Bangladesh under different weather and tidal cycles. Ecological Processes, 2(29): 1-13. DOI: 10.1186/2192-1709-2-29.

Rahman, F., Rahman, M.T., Rahman, M.S. and Ahmad, J. (2014). Organic production of Koromjol, Passur river system of the Sundarbans, Bangladesh. Asian Journal of Water, Environment and Pollution, 11(1): 95-103.

Rahman, M.M., Rahman, M.T., Rahaman, M.S., Rahman, F., Ahmad, J.U., Shakera, B. and Halim, M.A. (2013). Water quality of the world's largest mangrove forest. Canadian Chemical Transactions,1(2): 141-156. DOI: 10.13179/canchemtrans.2013.01.02.0018.

Ramamurthy, K., Radhika, A., Kavitha, A. and Raveendran, S. (2012). Physicochemical analysis of soil and water of Vedaranyam mangrove forest, Tamil Nadu, India. International Journal of Advanced Life Sciences, 3(1): 65-71. DOI: 10.20546/ijcmas.2018.705.268.

Rahaman, S.M.B., Rahaman, M.S., Ghosh,A.K., Gain, D., Biswas, S.K., Sarder, L., Islam, S.S. and Sayeed. A.B. (2015). A Spatial and Seasonal Pattern of Water Quality in the Sundarbans River Systems of Bangladesh. Journal of Coastal Research, 31(2): 390-397.

Sarkar, S., Ghosh, P.B., Das, T.M., Som, M.S. and Saha, T. (2013). Environmental assessment in terms of salinity distribution in the tropical mangrove forest of Sundarban, northeast coast of Bay of Bengal, India. Archives of Applied Science Research, 5(6): 109-118.

Senthilkumar, B., Purvaja, R. and Ramesh, R. (2008). Seasonal and tidal dynamics of nutrients and chlorophyll $a$ in tropical mangrove estuary, southeast coast of India. Indian Journal of Marine Sciences, 37(2): 132-140.

Suzuki, J.Y., Bollivar, D.W. and Bauer, C.E. (1997). Genetic analysis of chlorophyll $a$ biosynthesis. Annual Review of Genetics, 31(1): 61-89. DOI: 10.1146/annurev.genet.31.1.61.

USEPA (United States Environmental Protection Agency) (2008). Standard methods for the examination of water, wastewater and sea water. Method 8048. 
Table 1. Seasonal and tidal variation of physicochemical parameters with seasons

\begin{tabular}{|c|c|c|c|c|c|c|c|}
\hline \multirow{3}{*}{ Parameter } & \multicolumn{6}{|c|}{ Seasonal and Tidal Variation } & \multirow[t]{3}{*}{ Standard } \\
\hline & \multicolumn{2}{|c|}{ Pre-monsoon } & \multicolumn{2}{|c|}{ Monsoon } & \multicolumn{2}{|c|}{ Post-monsoon } & \\
\hline & HT & LT & HT & LT & HT & $\mathrm{LT}$ & \\
\hline $\begin{array}{l}\text { Temp. } \\
\left({ }^{\circ} \mathrm{C}\right)\end{array}$ & $\begin{array}{c}27.25 \pm 1.47 \\
(25.6 \text { to } 28.7)\end{array}$ & $\begin{array}{c}26.46 \pm 1.05 \\
(25.4 \text { to } 28.2)\end{array}$ & $\begin{array}{c}23.34 \pm 0.92 \\
(22.3 \text { to } \\
24.3)\end{array}$ & $\begin{array}{c}24.13 \pm 0.14 \\
(23.8 \text { to } 24.3)\end{array}$ & $\begin{array}{c}24.57 \pm 0.15 \\
(24.1 \text { to } 25.0)\end{array}$ & $\begin{array}{c}24.56 \pm 0.15 \\
(24.0 \text { to } 24.9)\end{array}$ & $\begin{array}{c}25 \text { to } 30 \text { (Rahaman et } \\
\text { al., 2013) }\end{array}$ \\
\hline $\mathrm{pH}$ & $\begin{array}{c}8.35 \pm 0.16 \\
(7.80 \text { to } 8.55) \\
\end{array}$ & $\begin{array}{l}8.52 \pm 0.09 \\
(8.2 \text { to } 8.7) \\
\end{array}$ & $\begin{array}{c}8.25 \pm 0.26 \\
(7.60 \text { to } 8.65) \\
\end{array}$ & $\begin{array}{l}8.29 \pm 0.06 \\
(8.0 \text { to } 8.6) \\
\end{array}$ & $\begin{array}{c}8.41 \pm 0.13 \\
\text { (7.96 to } 8.68) \\
\end{array}$ & $\begin{array}{l}8.57 \pm 0.06 \\
(8.3 \text { to } 8.7) \\
\end{array}$ & 6.5 to $8.5(\mathrm{DoE}, 2011)$ \\
\hline $\begin{array}{c}\mathrm{DO} \\
(\mathrm{mg} / \mathrm{L})\end{array}$ & $\begin{array}{c}9.84 \pm 1.04 \\
\text { (7.85 to } 11.68)\end{array}$ & $\begin{array}{c}9.79 \pm 0.78 \\
\text { (7.45 to } 11.48)\end{array}$ & $\begin{array}{c}9.56 \pm 1.34 \\
\text { (7.85 to } 12.54)\end{array}$ & $\begin{array}{c}10.41 \pm 0.83 \\
\text { (8.66 to } 12.48)\end{array}$ & $\begin{array}{c}10.6 \pm 0.78 \\
\text { (8.48 to } 13.13 \text { ) }\end{array}$ & $\begin{array}{c}10.31 \pm 2.02 \\
(8.65 \text { to } 14.39)\end{array}$ & $\begin{array}{c}7.5 \text { to } 8.5 \text { (Hoq et al., } \\
2007)\end{array}$ \\
\hline $\begin{array}{l}\text { Salinity } \\
(\%)\end{array}$ & $\begin{array}{c}0.17 \pm 0.03 \\
(0.13 \text { to } 0.25)\end{array}$ & $\begin{array}{c}0.16 \pm 0.02 \\
(0.12 \text { to } 0.21)\end{array}$ & $\begin{array}{c}0.14 \pm 0.01 \\
(0.09 \text { to } 0.19)\end{array}$ & $\begin{array}{c}0.13 \pm 0.01 \\
(0.09 \text { to } 0.19)\end{array}$ & $\begin{array}{c}0.24 \pm 0.06 \\
(0.17 \text { to } 0.36)\end{array}$ & $\begin{array}{c}0.23 \pm 0.04 \\
(0.16 \text { to } 0.32)\end{array}$ & $\begin{array}{c}0.5 \text { to } 30.0 \text { (Rahaman } \\
\text { et al., 2013) }\end{array}$ \\
\hline $\begin{array}{c}\mathrm{EC} \\
(\mu \mathrm{s} / \mathrm{cm})\end{array}$ & $\begin{array}{c}1599.79 \pm 961.73 \\
(756 \text { to } 3257)\end{array}$ & $\begin{array}{c}1945.53 \pm 1336.9 \\
(351 \text { to } 3857)\end{array}$ & $\begin{array}{c}1482.86 \pm 10006.2 \\
(712 \text { to } 2765)\end{array}$ & $\begin{array}{c}1795.13 \pm 1324.25 \\
(102 \text { to } 2790)\end{array}$ & $\begin{array}{l}1746.06 \pm 15.23 \\
(1706 \text { to } 1799)\end{array}$ & $\begin{array}{l}1742.99 \pm 21.01 \\
(1700 \text { to } 1789)\end{array}$ & >1500 (EQS, 1991) \\
\hline $\begin{array}{l}\text { TDS } \\
(\mathrm{ppm})\end{array}$ & $\begin{array}{l}1518 \pm 1069.81 \\
(638 \text { to } 3456)\end{array}$ & $\begin{array}{c}1812.86 \pm 1219.78 \\
\text { (351 to } 3461)\end{array}$ & $\begin{array}{c}988.33 \pm 799.87 \\
(306 \text { to } 2213)\end{array}$ & $\begin{array}{c}1400.12 \pm 1059.78 \\
\text { (213 to } 2244)\end{array}$ & $\begin{array}{c}1291.13 \pm 105.65 \\
\text { (1139 to } 1402)\end{array}$ & $\begin{array}{l}1371.39 \pm 40.95 \\
(1254 \text { to } 1448)\end{array}$ & $\begin{array}{c}500 \text { to } 30000 \text { (Wahid } \\
\text { et al., 2007) }\end{array}$ \\
\hline
\end{tabular}

Note: $\mathrm{HT}=$ High Tide, $\mathrm{LT}=$ Low Tide. 
Table 2: Seasonal and tidal dynamics of temperature, $\mathrm{pH}$ and DO in Sundarbans water

\begin{tabular}{|c|c|c|c|c|c|c|c|}
\hline \multirow[t]{2}{*}{ Stations } & \multirow[t]{2}{*}{ Season } & \multicolumn{2}{|c|}{ Temperature $\left({ }^{\circ} \mathrm{C}\right)$} & \multicolumn{2}{|c|}{$\mathrm{pH}$} & \multicolumn{2}{|c|}{ DO (mg/L) } \\
\hline & & $\mathrm{HT}$ & LT & $\mathrm{HT}$ & LT & HT & LT \\
\hline \multirow{3}{*}{$\mathrm{S} 1$} & Pre-monsoon & $25.66 \pm 0.06$ & $28.17 \pm 0.06$ & $8.47 \pm 0.06$ & $8.38 \pm 0.18$ & $11.00 \pm 1.0$ & $10.13 \pm 1.18$ \\
\hline & Monsoon & $22.37 \pm 0.06$ & $24.23 \pm 0.06$ & $8.4 \pm 0.2$ & $8.31 \pm 0.16$ & $9.54 \pm 1.16$ & $11.01 \pm 1.51$ \\
\hline & Post-monsoon & $24.73 \pm 0.25$ & $24.73 \pm 0.06$ & $8.41 \pm 0.14$ & $8.49 \pm 0.19$ & $11.87 \pm 1.51$ & $10.8 \pm 1.42$ \\
\hline \multirow{3}{*}{$\mathrm{S} 2$} & Pre-monsoon & $25.63 \pm 0.06$ & $26.57 \pm 0.15$ & $8.49 \pm 0.05$ & $8.61 \pm 0.10$ & $10.3 \pm 1.13$ & $9.79 \pm 0.42$ \\
\hline & Monsoon & $22.37 \pm 0.06$ & $23.9 \pm 0.17$ & $8.16 \pm 0.16$ & $8.25 \pm 0.13$ & $9.27 \pm 1.33$ & $9.79 \pm 1.21$ \\
\hline & Post-monsoon & $24.43 \pm 0.32$ & $24.83 \pm 0.12$ & $8.23 \pm 0.24$ & $8.66 \pm 0.05$ & $10.38 \pm 1.73$ & $9.54 \pm 0.56$ \\
\hline \multirow{3}{*}{ S3 } & Pre-monsoon & $28.47 \pm 0.25$ & $26.4 \pm 0.10$ & $8.06 \pm 0.25$ & $8.6 \pm 0.05$ & $8.52 \pm 0.62$ & $10.87 \pm 0.41$ \\
\hline & Monsoon & $23.63 \pm 0.59$ & $24.13 \pm 0.06$ & $7.82 \pm 0.19$ & $8.32 \pm 0.2$ & $8.12 \pm 0.31$ & $11.14 \pm 0.65$ \\
\hline & Post-monsoon & $24.6 \pm 0.10$ & $24.57 \pm 0.25$ & $8.55 \pm 0.07$ & $8.59 \pm 0.12$ & $10.29 \pm 2.2$ & $8.93 \pm 0.25$ \\
\hline \multirow{3}{*}{$\mathrm{S} 4$} & Pre-monsoon & $28.43 \pm 0.06$ & $25.57 \pm 0.21$ & $8.39 \pm 0.04$ & $8.52 \pm 0.03$ & $8.99 \pm 1.48$ & $8.79 \pm 1.67$ \\
\hline & Monsoon & $24.13 \pm 0.06$ & $24.17 \pm 0.06$ & $8.4 \pm 0.2$ & $8.2 \pm 0.22$ & $9.14 \pm 0.66$ & $9.26 \pm 0.53$ \\
\hline & Post-monsoon & $24.4 \pm 0.26$ & $24.57 \pm 0.23$ & $8.34 \pm 0.26$ & $8.6 \pm 0.07$ & $9.77 \pm 1.19$ & $10.95 \pm 2.22$ \\
\hline \multirow{3}{*}{ S5 } & Pre-monsoon & $28.06 \pm 0.06$ & $25.6 \pm 0.10$ & $8.33 \pm 0.15$ & $8.49 \pm 0.07$ & $10.4 \pm 0.50$ & $9.39 \pm 1.56$ \\
\hline & Monsoon & $24.23 \pm 0.06$ & $24.23 \pm 0.12$ & $8.45 \pm 0.23$ & $8.38 \pm 0.22$ & $11.46 \pm 1.09$ & $10.87 \pm 1.57$ \\
\hline & Post-monsoon & $24.7 \pm 0.30$ & $24.37 \pm 0.47$ & $8.52 \pm 0.14$ & $8.52 \pm 0.16$ & $10.68 \pm 2.23$ & $11.34 \pm 2.65$ \\
\hline
\end{tabular}

Note: $\mathrm{HT}=$ High Tide, $\mathrm{LT}=$ Low Tide.

\footnotetext{
Note: HT = High Tide, LT = Low Tide.
}

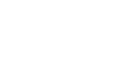


Table 3: Seasonal and tidal dynamics of salinity, EC and TDS in Sundarbans water

\begin{tabular}{|c|c|c|c|c|c|c|c|}
\hline \multirow[t]{2}{*}{ Stations } & \multirow[t]{2}{*}{ Season } & \multicolumn{2}{|c|}{ Salinity (\%o) } & \multicolumn{2}{|c|}{$\mathrm{EC}(\mu \mathrm{s} / \mathrm{cm})$} & \multicolumn{2}{|c|}{ TDS (ppm) } \\
\hline & & $\mathrm{HT}$ & LT & HT & $\mathrm{LT}$ & $\mathrm{HT}$ & LT \\
\hline \multirow{3}{*}{ S1 } & Pre-monsoon & $0.14 \pm 0.01$ & $0.13 \pm 0.02$ & $839 \pm 97.92$ & $446.33 \pm 101.1$ & $740.67 \pm 95.2$ & $423.33 \pm 70.5$ \\
\hline & Monsoon & $0.12 \pm 0.01$ & $0.13 \pm 0.03$ & $745.67 \pm 36.4$ & $343.33 \pm 319.3$ & $470.33 \pm 52.5$ & $258.67 \pm 14.3$ \\
\hline & Post-monsoon & $0.19 \pm 0.04$ & $0.19 \pm 0.03$ & $1757.33 \pm 13.2$ & $1758.33 \pm 17.7$ & $1198.33 \pm 23.4$ & $1369 \pm 42.3$ \\
\hline \multirow{3}{*}{ S2 } & Pre-monsoon & $0.15 \pm 0.01$ & $0.16 \pm 0.01$ & $1012.67 \pm 235.1$ & $558 \pm 285.7$ & $853.33 \pm 214.9$ & $647.67 \pm 103.3$ \\
\hline & Monsoon & $0.11 \pm 0.09$ & $0.14 \pm 0.05$ & $763.33 \pm 27.65$ & $345.67 \pm 390.4$ & $498 \pm 30.12$ & $221.67 \pm 13.32$ \\
\hline & Post-monsoon & $0.27 \pm 0.08$ & $0.19 \pm 0.02$ & $1754.67 \pm 26.7$ & $1758.33 \pm 49.7$ & $1157 \pm 22.34$ & $1431 \pm 27.73$ \\
\hline \multirow{3}{*}{ S3 } & Pre-monsoon & $0.15 \pm 0.02$ & $0.17 \pm 0.02$ & $848.67 \pm 87.2$ & $3241.33 \pm 583.3$ & $864 \pm 97.55$ & $2171 \pm 451.7$ \\
\hline & Monsoon & $0.12 \pm 0.02$ & $0.15 \pm 0.05$ & $751.33 \pm 34.3$ & $2755.33 \pm 19.4$ & $317 \pm 18.19$ & $2191.67 \pm 24.34$ \\
\hline & Post-monsoon & $0.19 \pm 0.03$ & $0.26 \pm 0.04$ & $1730.67 \pm 4.9$ & $1718.67 \pm 28.9$ & $1389.33 \pm 11$ & $1358.33 \pm 29.77$ \\
\hline \multirow{3}{*}{ S4 } & Pre-monsoon & $0.21 \pm 0.04$ & $0.19 \pm 0.01$ & $2582.33 \pm 624.3$ & $2614.67 \pm 622.1$ & $1892.33 \pm 104.9$ & $2664 \pm 121.01$ \\
\hline & Monsoon & $0.14 \pm 0.05$ & $0.12 \pm 0.03$ & $2404.67 \pm 586.4$ & $2768 \pm 19.47$ & $1520.67 \pm 303.5$ & $2220.67 \pm 25.77$ \\
\hline & Post-monsoon & $0.32 \pm 0.05$ & $0.28 \pm 0.04$ & $1728.33 \pm 36.12$ & $1721.33 \pm 21.83$ & $1363 \pm 15.52$ & $1381 \pm 9.54$ \\
\hline \multirow{3}{*}{ S5 } & Pre-monsoon & $0.19 \pm 0.02$ & $0.18 \pm 0.02$ & $2716.33 \pm 312.8$ & $2867.33 \pm 560.8$ & $3239.67 \pm 195.9$ & $3158.33 \pm 295.3$ \\
\hline & Monsoon & $0.14 \pm 0.02$ & $0.13 \pm 0.01$ & $2749.33 \pm 6.11$ & $2763.33 \pm 5.51$ & $2135.67 \pm 68.04$ & $2108 \pm 73.57$ \\
\hline & Post-monsoon & $0.22 \pm 0.03$ & $0.25 \pm 0.06$ & $1759.33 \pm 34.79$ & $1758.33 \pm 25.54$ & $1348 \pm 7.55$ & $1317.67 \pm 70.23$ \\
\hline
\end{tabular}

Note: $\mathrm{HT}=$ High Tide, $\mathrm{LT}=$ Low Tide. 
Table 4: Seasonal and tidal dynamics of ammonia, nitrate and phosphate in Sundarbans water

\begin{tabular}{|c|c|c|c|c|c|c|c|}
\hline \multirow[t]{2}{*}{ Station } & \multirow[t]{2}{*}{ Season } & \multicolumn{2}{|c|}{$\mathrm{NH}_{3}-\mathrm{N}(\mathrm{mg} / \mathrm{L})$} & \multicolumn{2}{|c|}{$\mathrm{NO}_{3}-\mathrm{N}(\mathrm{mg} / \mathrm{L})$} & \multicolumn{2}{|c|}{$\mathrm{PO}_{4}-\mathrm{P}(\mathrm{mg} / \mathrm{L})$} \\
\hline & & $\mathrm{HT}$ & LT & HT & LT & $\mathrm{HT}$ & $\mathrm{LT}$ \\
\hline \multirow{3}{*}{$\mathrm{S} 1$} & Pre-monsoon & $0.035 \pm 0.1$ & $0.037 \pm 0.1$ & $8.87 \pm 2.2$ & $10.4 \pm 0.6$ & $4.44 \pm 0.9$ & $2.48 \pm 0.3$ \\
\hline & Monsoon & $0.037 \pm 0.02$ & $0.043 \pm 0.02$ & $15.3 \pm 4.9$ & $14.9 \pm 8.93$ & $0.81 \pm 0.7$ & $0.48 \pm 0.2$ \\
\hline & Post-monsoon & $0.05 \pm 0.01$ & $0.05 \pm 0.02$ & $27.33 \pm 20.5$ & $31.67 \pm 13.9$ & $0.67 \pm 0.2$ & $1.1 \pm 0.3$ \\
\hline \multirow{3}{*}{$\mathrm{S} 2$} & Pre-monsoon & $0.002 \pm 0.001$ & $0.087 \pm 0.01$ & $11.47 \pm 0.46$ & $7.8 \pm 1.5$ & $0.36 \pm 0.05$ & $0.55 \pm 0.04$ \\
\hline & Monsoon & $0.027 \pm 0.02$ & $0.023 \pm 0.02$ & $21.23 \pm 3.73$ & $9.57 \pm 8.44$ & $0.39 \pm 0.14$ & $0.74 \pm 0.8$ \\
\hline & Post-monsoon & $0.06 \pm 0.03$ & $0.06 \pm 0.02$ & $10.33 \pm 6.81$ & $18.33 \pm 6.51$ & $0.69 \pm 0.17$ & $1.2 \pm 0.13$ \\
\hline \multirow{3}{*}{ S3 } & Pre-monsoon & $0.057 \pm 0.02$ & $0.177 \pm 0.19$ & $9.7 \pm 2.46$ & $8.6 \pm 1.47$ & $0.46 \pm 0.09$ & $0.49 \pm 0.1$ \\
\hline & Monsoon & $0.05 \pm 0.01$ & $0.033 \pm 0.02$ & $19.9 \pm 6.65$ & $18.2 \pm 6.1$ & $0.28 \pm 0.2$ & $0.50 \pm 0.11$ \\
\hline & Post-monsoon & $0.05 \pm 0.03$ & $0.05 \pm 0.02$ & $31.67 \pm 7.64$ & $31.33 \pm 4.04$ & $0.84 \pm 0.1$ & $1.11 \pm 0.1$ \\
\hline \multirow{3}{*}{ S4 } & Pre-monsoon & $0.057 \pm 0.03$ & $0.073 \pm 0.02$ & $7.23 \pm 3.4$ & $8.63 \pm 1.69$ & $0.46 \pm 0.1$ & $0.62 \pm 0.13$ \\
\hline & Monsoon & $0.043 \pm 0.03$ & $0.043 \pm 0.02$ & $22.9 \pm 2.7$ & $17.9 \pm 2.61$ & $0.79 \pm 0.43$ & $0.15 \pm 0.1$ \\
\hline & Post-monsoon & $0.04 \pm 0.02$ & $0.06 \pm 0.03$ & $26 \pm 14.18$ & $19.67 \pm 6.66$ & $1.27 \pm 0.25$ & $1.31 \pm 0.5$ \\
\hline \multirow{3}{*}{ S5 } & Pre-monsoon & $0.024 \pm 0.02$ & $0.02 \pm 0.02$ & $10.13 \pm 2.02$ & $11.23 \pm 0.91$ & $0.92 \pm 0.12$ & $0.6 \pm 0.04$ \\
\hline & Monsoon & $0.03 \pm 0.01$ & $0.03 \pm 0.02$ & $16.03 \pm 7.02$ & $25.47 \pm 2.57$ & $0.36 \pm 0.1$ & $0.26 \pm 0.1$ \\
\hline & Post-monsoon & $0.06 \pm 0.03$ & $0.04 \pm 0.02$ & $17.67 \pm 6.5$ & $15 \pm 5$ & $1.57 \pm 0.5$ & $1.03 \pm 0.21$ \\
\hline
\end{tabular}

Note: $\mathrm{HT}=$ High Tide, $\mathrm{LT}=$ Low Tide. 
Table 5: Seasonal and tidal dynamics of sulfate and Chlorophyll $a$ concentration in Sundarbans water

\begin{tabular}{|c|c|c|c|c|c|}
\hline \multirow[t]{2}{*}{ Station } & \multirow[t]{2}{*}{ Season } & \multicolumn{2}{|c|}{$\mathrm{SO}_{4}(\mathrm{mg} / \mathrm{L})$} & \multicolumn{2}{|c|}{ Chlorophyll $a(\mathrm{mg} / \mathrm{L})$} \\
\hline & & HT & LT & HT & LT \\
\hline \multirow{3}{*}{$\mathrm{S} 1$} & Pre-monsoon & $153 \pm 17.06$ & $159 \pm 12.12$ & $153 \pm 17.06$ & $159 \pm 12.12$ \\
\hline & Monsoon & $40.67 \pm 11.02$ & $41.33 \pm 6.51$ & $40.67 \pm 11.02$ & $41.33 \pm 6.51$ \\
\hline & Post-monsoon & $40 \pm 12.17$ & $90 \pm 26.46$ & $40 \pm 12.17$ & $90 \pm 26.46$ \\
\hline \multirow{3}{*}{ S2 } & Pre-monsoon & $264 \pm 8$ & $136 \pm 9.64$ & $264 \pm 8$ & $136 \pm 9.64$ \\
\hline & Monsoon & $48.67 \pm 12.06$ & $35 \pm 15.13$ & $48.67 \pm 12.06$ & $35 \pm 15.13$ \\
\hline & Post-monsoon & $83.33 \pm 40.41$ & $86.33 \pm 25.79$ & $83.33 \pm 40.41$ & $86.33 \pm 25.79$ \\
\hline \multirow{3}{*}{ S3 } & Pre-monsoon & $198 \pm 16.37$ & $76 \pm 7$ & $198 \pm 16.37$ & $76 \pm 7$ \\
\hline & Monsoon & $40 \pm 9.17$ & $46 \pm 7.94$ & $40 \pm 9.17$ & $46 \pm 7.94$ \\
\hline & Post-monsoon & $99 \pm 29.21$ & $111.33 \pm 16.44$ & $99 \pm 29.21$ & $111.33 \pm 16.44$ \\
\hline \multirow{3}{*}{ S4 } & Pre-monsoon & $192 \pm 18.73$ & $135 \pm 13.08$ & $192 \pm 18.73$ & $135 \pm 13.08$ \\
\hline & Monsoon & $79.33 \pm 9.02$ & $75.67 \pm 5.13$ & $79.33 \pm 9.02$ & $75.67 \pm 5.13$ \\
\hline & Post-monsoon & $82 \pm 11.27$ & $102.67 \pm 13.01$ & $82 \pm 11.27$ & $102.67 \pm 13.01$ \\
\hline \multirow{3}{*}{ S5 } & Pre-monsoon & $132 \pm 11.36$ & $171 \pm 8$ & $132 \pm 11.36$ & $171 \pm 8$ \\
\hline & Monsoon & $57.33 \pm 29.69$ & $31 \pm 10.15$ & $57.33 \pm 29.69$ & $31 \pm 10.15$ \\
\hline & Post-monsoon & $80 \pm 36.06$ & $88.33 \pm 20.79$ & $80 \pm 36.06$ & $88.33 \pm 20.79$ \\
\hline
\end{tabular}

Note: $\mathrm{HT}=$ High Tide, $\mathrm{LT}=$ Low Tide.

Table 6: Comparison of chlorophyll $a$ and water nutrients of Sundarbans with other estuaries.

\begin{tabular}{l|c|c|c|c|c|c}
\hline $\begin{array}{l}\text { Parameters } \\
(\mathrm{mg} / \mathrm{L})\end{array}$ & Present Study & $\begin{array}{c}\text { Rahaman } \text { et al., } \\
2013\end{array}$ & $\begin{array}{c}\text { Prasad } \text { et al., } \\
2008\end{array}$ & $\begin{array}{c}\text { Senthilkumar } \text { et al., } \\
2008\end{array}$ & $\begin{array}{c}\text { Prasad } \text { et al., } \\
2008\end{array}$ & $\begin{array}{c}\text { Standard } \\
(\mathrm{EPA}, 2017)\end{array}$ \\
\hline Chlorophyll $a$ & 0.91 & $\mathrm{Nd}$ & $\mathrm{Nd}$ & 10.02 & $\mathrm{Nd}$ & $0.06-0.59$ \\
\hline $\mathrm{NH}_{3}-\mathrm{N}$ & 0.05 & 0.14 & $\mathrm{Nd}$ & 63.60 & 11.80 & \\
\hline $\mathrm{NO}_{3}-\mathrm{N}$ & 17.05 & 0.15 & 6.62 & 3.90 & 6.08 & 0.1 \\
\hline $\mathrm{PO}_{4}-\mathrm{P}$ & 0.95 & 0.12 & 0.41 & 3.25 & 61.33 & $0.005-0.20$ \\
\hline $\mathrm{SO}_{4}$ & 105.90 & 95.69 & 0.30 & $\mathrm{Nd}$ & $\mathrm{Nd}$ & $2-70$ \\
\hline
\end{tabular}

